\title{
Effect of different packaging materials on bacteriological quality of "Egidi" ${ }^{1}$ Ajala Lola*, ${ }^{1}$ Ibrahim T.A and ${ }^{2}$ Adebote, $V$ T \\ ${ }^{1}$ Department of Food Science and Technology Rufus Giwa Polytechnic, P.M.B 1019, Owo, Ondo State,Nigeria. \\ ${ }^{2}$ Department of Science Laboratory Technology \\ Rufus Giwa Polytechnic, P.M.B 1019, Owo, Ondo State,Nigeria. *corresponding author:Iola_ajala2006@yahoo.co.uk
}

\begin{abstract}
"Egidi" a cereal based food was collected at the point of production for the evaluation of effect of different packaging on the bacteriological quality using standard microbiological methods. The results showed that the initial bacterial load of the Egidi was $23 \times 10^{3} \mathrm{cfu} / \mathrm{g}$. The total bacterial count ranged from 33 to $134 \times 10^{3} \mathrm{cfu} / \mathrm{g}$ for Egidi packed with nylon, $28 \times 10^{3} \mathrm{cfu} / \mathrm{g}$ for 'egidi' packed in aluminium foil and 39 to $168 \times 10^{3} \mathrm{cfu} / \mathrm{g}$ for egidi packed in banana leaves for 3 weeks. The bacterial isolates were identified as Staphylococcus $s p$, E.coli, Proteus $s p$, Enterobacter $s p$, Pseudomonas sp, and Klebsiella sp and Bacillus sp.
\end{abstract}

Keywords: Egidi, Packaging, Bacterial, Quality, Evaluation.

\section{INTRODUCTION}

Packaging materials have been known to be possible source of microbial contamination of food (Faseyi,1996). Since food eaten has a direct influence on health, it is therefore important that manufacturer and food handlers keep food safe from pathogenic microorganisms (Hicks,2003). Cellophane is the largest volume of single film used in flexible packaging industry. It is a low cost film with moderate tensile strength and clarity, and is a good moisture barrier. Local packaging alternatives include leaves of plants such as banana, cocoa, cocoyam, etc which are large caudate leaf borne on petiole of 2 to $4 \mathrm{~cm}$ long. These plants occur wide in the African rain forest, large, cheap, and readily available and provide good packaging for products that are quickly consumed. They are common in the lowland tropics of Africa, Central Latin America, Southeast Asia and West Indies. Although, the leaves of these plants are used as wrapping materials, little is recorded on the microbiological qualities of the food items wrapped in them. Packaging is one area that has attracted attention because the use of suitable materials for cooked foods improves shelf life and contributes to the wholesomeness of the product. As a result of growing number of urban dwellers who are becoming increasingly dependent on street cooked food and given the number and importance of those working in the food trade, it is important to examine the type of packaging materials used by vendor and their effect on the quality of the product (Tillotson, 1984).
'Egidi' which is also called 'kati' is a traditional cereal based ready to eat food found in the south west region of Nigeria. It is domestically prepared and commonly hawked along the streets or displayed in the market (Omosuli et al ,2008). There is often unacceptable high level of hand contact with the foods on display which easily lead to contamination of such goods (WHO,2002).It is produced mainly from fermented sorghum slurry and wrapped in leaves. It can be store for upward of ten days without refrigeration and longer when refrigerated. It is usually used for snacking in a hot afternoon by breaking it into cold water. The aim of the research work is to use different packaging materials for the 'Egidi' and examine its effects to the bacteriological quality of the product

\section{MATERIALS AND METHODS}

Materials Collection: The 'Egidi' used in this research was collected at the site of production while the other packaging materials were brought at OjaOba market in Ikare Akoko, Ondo State, Nigeria.

Sample Collection: Sample of 'Egidi' was collected at a production site at Arigidi-Akoko, Ondo State, Nigeria, a locality noted for its consumption. Samples were aseptically collected into different packaging materials (Banana leaves, nylon and aluminium foil) at the point of production.

Bacteriological Analysis: - The Egidi samples were subjected to total plate count and total coliform count using general purpose media (Nutrient agar) 
selective media and differential media (MacConkey agar) Eosin Methylene Blue, EBS and Mannitol salt agar. All media were prepared according to manufacturer's specification. From the 10-fold dilutions of the sample homogenates, $0.1 \mathrm{ml}$ of the $10^{5}$ dilution were plated on different media using the pour plate method of Cheesebrough (2003) to estimate the bacteriological quality of the samples initially and every 48 hours. The plates were incubated at $37^{\circ} \mathrm{C}$ for $24-48$ hours.

\section{Characterization and Identification of Isolates :} Distinct colonies from both bacteriological analyses (total Plate and total coliform count) were examined for cultural characteristics such as shape, colour, seize, elevation, gram staining and biochemical tests such as catalase, coagulase, oxidase, motility and sugar utilization as described by Cheesbrough (2003). Identification of the isolates was done by comparing their characteristics with those of known taxa as described in Bergey's manual for Determinative Bacteriology (Buchanan and Gribbon, 1974).

\section{RESULTS AND DISCUSSION}

The total bacterial count of Egidi was given in table 1 . A total of 2034 bacterial isolates were obtained from the analysis from Egidi wrapped with nylon, banana leaves and aluminium foil for 21 days. The Egidi wrapped with nylon has a total bacterial count of $697 \mathrm{cfu} / \mathrm{g}$, aluminium foil has $526 \mathrm{cfu} / \mathrm{g}$ while banana leaves has $814 \mathrm{cfu} / \mathrm{g}$. The result showed that Egidi wrapped with banana leaves has the highest bacterial isolates followed by nylon while aluminium foil has the least count. Thus it showed that the capacity of the packaging material can be monitored using the bacterial count of the contents. From this, it showed that the foil has the best packaging property , followed by the nylon while the leaves has the least .Table 2 showed the biochemical characteristics of the distinct pure bacterial isolates from the Egidi samples. Among the most propable organisms identified after comparing their gram staining reaction results, biochemical tests and sugar utilization with those of known taxa as described by Cheesebrough (2003) were Staphylococcus sp, E.coli, Proteus sp, Enterobacter sp, Pseudomonas sp, and Klebsiella sp.Staphylococcus $s p$ were the only gram positive while others were gram negative. All the gram negative organisms were citrate positive except Proteus sp and Enterobacter sp, all were methyl red positive except E.coli and coliform, all were catalase positive except Enterobacter sp while only Enterobacter sp, Serratia sp, Proteus sp and Pseudomonas sp were motile. The presence of Klebsiella sp, Coliform , Proteus sp in the Egidi should be given a special attention because they indicate public health hazard and could be a possible occurrence of foodborne intoxication (Kabir, 2009) while it's been noted that the presence of coagulase positive Staphylococcus $\mathrm{sp}$ is largely as a result of human contact which indicates that time and temperature abuse of a food is likely to have occurred following improper handling during food preparation even during the analysis (PHLS,2000). Pseudomonas $\mathrm{sp}$ and Serratia $\mathrm{sp}$ are pathogenic organisms of public health significance and concern (Adak et al;2005).

These organisms are usually associated with foods as reported by Oyeleke (2009) and in line with the findings of Omosuli et al (2008) in their analysis of produced and hawked Egidi in Ikare metropolis. The presence of these bacterial species and their differences in colony forming unit per gram (cfu/mg) values are more likely to be due to deposition of organisms on the food rather than their differential growth. The need for bacteriological assessment of indigenous food packaged with different materials is therefore emphasized and recommended because most of them are held at ambient temperature for days which could be a major factor contributing to outbreak of foodborne diseases (Bryan, 1990).

Table 1: Total bacterial load of the Egidi packaged with different materials for 21 days

\begin{tabular}{|c|c|c|c|c|c|c|c|c|c|c|}
\hline & $0 \mathrm{hr}$ & Day 3 & Day 5 & Day 7 & Day 9 & Day 11 & Day 15 & Day 17 & Day 19 & Day 21 \\
\hline $\begin{array}{l}\left(10^{3} \mathrm{cfu} / \mathrm{g}\right) \\
\text { Nylon }\end{array}$ & 23 & 33 & 45 & 57 & 63 & 71 & 88 & 96 & 114 & 134 \\
\hline Foil & 23 & 28 & 33 & 42 & 48 & 55 & 63 & 72 & 86 & 99 \\
\hline Leaves & 23 & 39 & 51 & 59 & 67 & 81 & 96 & 121 & 132 & 168 \\
\hline
\end{tabular}


Table 2: Biochemical Characteristics of Bacterial isolates from the Egidi wrapped with different Packaging Materials.

\begin{tabular}{|c|c|c|c|c|c|c|c|c|}
\hline \multirow[t]{2}{*}{ Parameters } & \multicolumn{8}{|c|}{ Pure Isolates Identified } \\
\hline & $\mathrm{I}$ & II & III & IV & $\mathrm{V}$ & $\mathrm{VI}$ & VII & VIII \\
\hline Gram Reaction & + & - & - & - & - & - & - & - \\
\hline Motility & & & + & & + & & + & + \\
\hline Catalase & + & + & + & + & + & + & + & _- \\
\hline Coagulase & $+/-$ & - & - & - & - & + & - & + \\
\hline Oxidase & - & - & + & - & - & - & - & - \\
\hline Citrate & _ & + & + & + & - & + & + & _- \\
\hline Urease & + & - & - & + & + & - & + & + \\
\hline Methyl Red & & & + & + & + & . & + & + \\
\hline Glucose & A & $\bar{A}$ & A & A & A & $\bar{A}$ & A & A \\
\hline Lactose & - & $A$ & - & A & - & $A$ & $A$ & $A$ \\
\hline Manitol & $A /-$ & A & A & A & & A & - & A \\
\hline Sucrose & A & A & - & A & $\bar{A}$ & A & - & A \\
\hline Most Propable Bacteria & STAPH & ECOLI & PSEU & KLEB & PROT & COLI & SERA & ENTR \\
\hline
\end{tabular}

$+=$ positive,$--=$ negative, $\mathrm{A}=$ Acid production, STAPH=Staphylococcus sp , ECOLI=E. coli, $\mathrm{PSEU}=$ Pseudomonas $\mathrm{sp}, \mathrm{KLEB}=$ Klebsiella $\mathrm{sp}, \mathrm{PROT}=$ Proteus $\mathrm{sp}, \mathrm{COLI}=$ Coliforms,SERA= Serratia $\mathrm{sp}$, ENTR= Enterobacter sp

\section{CONCLUSION}

Proper hygienic condition and effective packaging with the right packaging materials are important measures to reduce chances of food contamination, spoilage and it's implication in foodborne diseases. It showed from this study that aluminium foil had the best packaging property followed by the nylon and least by the wrapping leaves of banana.

\section{REFERENCES}

Tillotson J E (1984): Aseptic Packaging of Fruit Juice .American Journal of Food Technology, 34,(5)Pg 1414-1421.

Faseyi C O (1996): Effect of Processing, Packaging Materials and Storage Period on the Customer Acceptability of Akara. Nigerian Food Journal,Vol.1 no 14,Pg. 40-51.

Hicks P.A (2003): The Principles of Food Packaging. Chagrin Publisher, Asia, 3rd edition, Pg 12- 25.

Adak G.K, Meakins S.M, yip H,Lopman B.A, and O'Brien S.J(2005).Diseases risk from foods. England and Wales 1996-2000. Emerging Infectious Diseases.www.cdc.gov/ncidod/EID/vol.11, no.03/040191.htm.

Buchana R.E and Gribbons N.E (1974).Bergey's Manual of Determinative Bacteriology.( $8^{\text {th }}$ edition)Williams and Wilkins Co,Baltimore, U.S.A
Cheesbrough M (2002) Medical Laboratory Manual. Tropical Health Technology, Low Priced Edition.Doddington, Cambridgeshire, England; pp146215.

Kabir S.M (2009).Effect of Probiotics on broiler meat quality. African Journal of Biotechnology.8 (15)36233727.

Oyeleke S.B (2009).Microbial assessment of some commercially prepared yoghurt retailed in Minna, Niger State, Nigeria. African Journal of Microbiology Research,3 (5)245-248.

Omosuli S.V ,Opawale B.O and Ibrahim T.A(2008). A survey of bacterial content of 'Egidi' and 'Eko' produced and hawked in Ikare Akoko, Ondo State,Nigeria.Ikere Journal of the science Teacher,pp.114-117.

WHO (2000).|Global Strategy for food Safety, Geneva: WHO (ISBN9241545747).

PHLS (Public Health Laboratory Science)(2000).Guideline for the bacteriological quality of ready to eat food samples at the point of Sale. Communicable Diseases and Public Health, No.3pp67-82.

Bryan F.C (1990).Risk of Practises, Procedure and Processes that lead to outbreak of food borne diseases. Journal of Food Protection, 3(5)287-294. 